\title{
Nymph and Adult Biology of Euschistus cornutus Dallas: a Potential Soybean Pest in the Neotropics
}

\author{
AR PANIZZI $1^{1} \oplus$, NF WEBBER ${ }^{2}$, T LUCINI $^{3}$ \\ 'Lab of Entomology, Embrapa Wheat, Passo Fundo, RS , Brasil \\ ${ }^{2}$ Dept of Agronomy, Univ of Passo Fundo, Passo Fundo, RS, Brasil \\ ${ }^{3}$ Dept of Zoology, Federal Univ of Paraná, P.O. Box 19020, Curitiba, PR, Brasil
}

\section{Keywords}

Heteroptera, Pentatomidae, stink bug, host plants

\section{Correspondence \\ AR Panizzi, Lab of Entomology, Embrapa Wheat, Passo Fundo, RS 99001-970, Brasil; antonio.panizzi@embrapa.br}

Edited by Marcelo N Rossi - UNIFESP

Received 16 August 2016 and accepted 8 November 2016

Published online: 15 December 2016

(C) Sociedade Entomológica do Brasil 2016

\begin{abstract}
Laboratory studies with Euschistus cornutus Dallas indicated that nymphs complete development when feeding on green bean, Phaseolus vulgaris $\mathrm{L}$. pod, on soybean, Glycine max (L.) Merrill pod, and on raw shelled peanut, Arachis hypogaea L., but not on fruit (berry) of privet, Ligustrum lucidum Ait. Total mortality was lower on green bean pod $(45 \%)$, and higher on soybean pod and peanut raw ( 75 and $80 \%$, respectively). Nymph developmental time was significantly longer for females feeding on green bean pod (37.4 days) than on soybean pod ( 27 days); a single data was observed on peanut raw ( 32 days). Males showed no significant differences in total nymph developmental time among foods (31.3 to 33.0 days). At adult emergency, fresh body weight of females $(52.2$ to $68.5 \mathrm{mg}$ ) and males (61.9 to $71.3 \mathrm{mg}$ ) did not show statistical differences among foods tested nor between genders. Survivorship of $E$. cornutus adult after 50 days was greater on peanut raw than on green bean or soybean pod; on privet berry, the majority of males and females (>80\%) were dead after 20 days. The reproductive performance data was, in general, greater on peanut raw than on green bean or soybean pod; on privet fruit, no female laid eggs. Fresh body weight gain occurred on all foods, except on privet berry, on which adults lost weight over time. Records of specimens from insect collections in Brazil indicated that $E$. cornutus occurs in the Southeast and South regions $\left(19^{\circ}\right.$ to $31^{\circ} \mathrm{S}$ latitude). The most common host plant is soybean, suggesting a potential pest status of this stink bug on this crop in the future.
\end{abstract}

\section{Introduction}

Stink bugs of the genus Euschistus Dallas comprise ca. 70 species distributed in the Neotropical region (Barth \& Grazia 2012) and, at least, 19 species distributed in the Nearctic region (Froeschner 1988); this genus is one of the biggest within the subfamily Pentatominae. In the Nearctic region, the most common species is Euschistus servus (Say), whereas in the Neotropical region, Euschistus heros (F.) is the most abundant, both pest of soybean [Glycine max (L.) Merrill]. E. heros was rarely found in the neotropics up to the 1970 decade (Panizzi et al 1977), but nowadays, it is widespread causing significant damages to soybean and other crops, mostly in Brazil and in other countries of South America (Panizzi et al 2012); recently, it was reported damaging soybean in Argentina (Saluso et al 2011). Because of the great number of species of Euschistus occurring in the neotropics, more species are expected to become pests of economic plants cultivated in this region.

Euschistus cornutus Dallas was reported as the most abundant species in the genus Euschistus in South America in the 1980s (Rolston 1982). It is considered a species 
inhabiting preferably natural forests in the neotropics, and, because of its non-pest status, very little information about its bioecology is available in the literature. Despite of that, a survey made in entomological collections in Brazil showed that the majority of the individuals from cultivated plants were collected from the soybean crop in the Southern region of Brazil. In addition, E. cornutus was reported to be also present in Argentina and Paraguay (Kirkaldy 1909).

In recent visits $(2015 / 2016)$ to soybean fields in Southwestern region of Paraná state, Brazil, several individuals (nymphs and adults) of $E$. cornutus were collected on this crop during the reproductive period (at pod-filling R5 stage of Fehr et al (1971)). Similar to what has occurred with $E$. heros, which was rare and became extremely abundant on soybean, $E$. cornutus may have potential to become a soybean pest in the future. Therefore, we studied the nymph and adult biology of $E$. cornutus on soybean pod, on green bean (Phaseolus vulgaris L.), on raw shelled peanut (Arachis hypogaea L.), and on fruit (berry) of privet, Ligustrum lucidum Ait., these last three foods commonly used to rear stink bugs in our laboratory.

\section{Material and Methods}

\section{Stink bug colonies}

Adults and nymphs of $E$. cornutus were collected on soybean plants, and on two wild plants, Solanum atropurpureum L. (Solanaceae) and on Hybanthus bigibbosus (St. Hil.) Haffl. (Violaceae) growing nearby soybean fields in Francisco Beltrão Co. $\left(26^{\circ} \mathrm{O} 4^{\prime} \mathrm{S} ; 53^{\circ} \mathrm{O} 3^{\prime} \mathrm{W}\right)$, in Paraná state, Brazil. The stink bugs were taken to the Laboratory of Entomology of the Embrapa Wheat Research Center located in Passo Fundo, $\mathrm{RS}$, Brazil $\left(28^{\circ} 15^{\prime} \mathrm{S} ; 52^{\circ} 24^{\prime} \mathrm{W}\right)$, where a colony was established. They were placed into plastic cages $(25 \times 20 \times 20 \mathrm{~cm})$ lined with filter paper. The cages were kept in a walk-in chamber at $25 \pm 1^{\circ} \mathrm{C}, 65 \pm 10 \%$ relative humidity, and photoperiod of 14L:10D hours.

As food, a standard food source routinely used in our laboratory to rear several species of phytophagous stink bugs was used composed by fresh green bean pod, mature soybean seed, raw shelled peanut, and fruit (berry) of privet, which was replaced once a week. From the rearing cages, eggs were collected daily and placed inside small plastic boxes $(11 \times 11 \times 3.5 \mathrm{~cm})$ containing the foods mentioned above, with wet cotton on a plastic lid $(2 \mathrm{~cm}$ diameter, used to provide water) to obtain nymphs and adults.

\section{Nymph biology of E. cornutus on different food sources}

This study was conducted during January 2015 to February 2015 in the Laboratory of Entomology of the Embrapa Wheat research unit. On the first day of the second instar (first instars stay grouped and do not feed), nymphs were separated from the rearing boxes and placed into small Petri dishes $(6.0 \times 1.0 \mathrm{~cm})$ lined with a filter paper, and fed with the following foods ( 20 nymphs/food): fresh green bean pod, soybean pod at pod-filling R5 stage, raw shelled peanut, and fruit (berry) of privet. These foods were chosen because they are used as a standard food to rear stink bugs in the laboratory. To provide water, wet cotton placed on a plastic lid ( $2 \mathrm{~cm}$ diameter) was offered.

The Petri dishes were placed randomly in an environmental chamber maintained at $25 \pm 1^{\circ} \mathrm{C}$ and $65 \pm 5 \% \mathrm{RH}$ and photoperiod of $14 \mathrm{~L}: 10 \mathrm{D}$. Every day observations were made to check for nymph survivorship and instar change, to determine the following parameters: nymph developmental time, percentage of mortality of each instar, and developmental time from second instar to adult. At adult emergence, the sex was determined and its fresh body was measured using an electronic balance (Sartorius model BP210S).

\section{Adult biology of E. cornutus on different food sources}

This study was conducted from March to July 2015 in the Laboratory of Entomology of the Embrapa Wheat to evaluate adult survivorship and reproduction. Adults were obtained from additional nymphs reared in the laboratory using the foods described for keeping the stink bugs colonies above. On the day of emergence, 40 pairs were separated and had their weight taken; after that, the female/male pairs were individually placed in a plastic rearing box $(11 \times 11 \times 3.5 \mathrm{~cm})$ lined with filter paper. Water was provided as described for the nymph biology. Adult performance was evaluated on the following foods ( $n=10$ pairs in each food): fresh green bean pod, soybean pod at pod-filling R5 stage, raw shelled peanut, and fruit (berry) of privet. The boxes were placed randomly in an environmental chamber maintained at $25 \pm 1^{\circ} \mathrm{C}$ and 65 $\pm 5 \% \mathrm{RH}$ and photoperiod of $14 \mathrm{~L}: 10 \mathrm{D}$.

Daily observations were made to determine females and males' survivorship up to 50 days, and reproduction (egg masses and total eggs) and egg fertility. Adults (females and males) had their weight measured every 7 days during 4 weeks. The following parameters were calculated: percentage of females ovipositing, mean pre-oviposition time, mean number of egg masses and eggs per female, percentage of egg hatched, and percent fresh adult body weight change of females and males over time. Because the number of adults reaching the fourth week was small, fresh body weight change was calculated considering both males and females together.

Data from the nymph and adult biology studies were submitted to analysis of variance (ANOVA), and means were separated applying the Tukey's test $(P<0.05)$ using the $\mathrm{R}$ program (R Development Core Team 2014). 


\section{Results}

\section{Nymph biology of E. cornutus on different food sources}

The laboratory studies with $E$. cornutus nymphs indicated that they were able to complete development when fed on green bean pod (GBP), soybean pod (SB), and peanut raw $(P R)$, but not on privet berry (PB). The mortality for each instar was variable according to food source provided; however, the total mortality was lower on green bean pod (45\%), and higher on soybean pod and peanut raw (75 and 80\%, respectively) (Table 1). The mortality rate on each instar was variable according to food source provided; on green bean pod and peanut raw, the second instar presented the highest mortalities ( 25 and $40 \%$, respectively), whereas on soybean pod, the mortality was higher at the fifth instar (40\%).

Nymph developmental time among food sources varied significantly $(P<0.05)$ only during the second instar, which on soybean pod, nymphs took less time (6.9 days) to complete its development compared to peanut raw (11.1 days); however, it was not statistically different of green bean pod (9.2 days). On privet fruit, no nymphs pass to the third instar. The total developmental time to reach adulthood was significantly longer for females feeding on green bean pod (37.4 days) than on soybean pod ( 27 days); a single data was observed on peanut raw (32 days), and it was not included in the statistical analysis. Regarding males, no significant differences in total nymph developmental time among foods was observed, which ranged from 31.3 to 33.0 days (Table 1).

At the adult emergency day, fresh body weight of both, females and males, did not show statistical differences among foods on which nymphs completed development, i.e., green bean pod, soybean pod, and peanut raw, on which body weight ranged from 52.2 to $68.5 \mathrm{mg}$ for females and 61.9 to $71.3 \mathrm{mg}$ for males. The weights between females and males in each food were similar $(\mathrm{GBP}=68.5$ and $71.0 \mathrm{mg}$; $\mathrm{SP}=67.9$ and $71.3 \mathrm{mg}$; and $\mathrm{PR}=52.2$ and $61.9 \mathrm{mg}$, respectively). In general, there was a tendency of adults to weigh less on peanut raw compared to green bean or soybean pod, but no statistical differences were observed.

\section{Adult biology of E. cornutus on different food sources}

Survivorship of E. cornutus adult over 50 days showed a sharp decrease after 10 days in all food sources, except on peanut raw (Fig 1). This last food showed the highest survivorship values at all 10-days intervals during 50 days, to both, females and males ( 60 and $50 \%$, respectively on day 50 ). On green bean pod and soybean pod, females showed a similar survivorship values after 50 days ( 50 and $40 \%$, respectively) (Fig 1a); whereas for males, there was a bigger difference between these foods (50 and 20\%, respectively) (Fig $1 \mathrm{~b}$ ). On privet berry, the majority of males and females $(>80 \%)$ were dead after 20 days (Fig 1).

The reproductive performance data showed that the percentage of females that oviposited varied from 40 to $60 \%$ among foods, with peanut raw and green bean pod presenting the highest values, followed by soybean pod; on privet fruit, no female laid eggs (Table 2). The pre-oviposition period of females did not show statistical differences among foods, despite the tendency of longer time on green bean compared to that on soybean pod and peanut raw.

For fecundity, considering the number of egg masses per female, there were significant differences, with females

Table 1 Mean $( \pm$ SEM) developmental time and survivorship of Euschistus cornutus nymphs feeding on different food sources in laboratory conditions.

\begin{tabular}{|c|c|c|c|c|c|c|}
\hline \multirow{2}{*}{$\begin{array}{l}\text { Food source } \\
\text { [Initial \# of nymphs] }^{\text {a }}\end{array}$} & \multicolumn{4}{|l|}{ Stadium duration (days) } & \multicolumn{2}{|c|}{$\begin{array}{l}\text { Total developmental time } \\
\text { (days) }^{\mathrm{b}}\end{array}$} \\
\hline & Second & Third & Fourth & Fifth & Female & Male \\
\hline $\begin{array}{l}\text { Green bean pod } \\
{[20](45 \%)^{\mathrm{b}}}\end{array}$ & $9.2 \pm 0.61 a b[18](10 \%)^{a}$ & $7.9 \pm 0.77 a[13](25 \%)$ & $7.7 \pm 0.34 a[12](5 \%)$ & $11.6 \pm 0.78 a[11](5 \%)$ & $37.4 \pm 0.73 a[7]$ & $32.5 \pm 0.52 a[4]$ \\
\hline $\begin{array}{l}\text { Soybean pod } \\
{[20](75 \%)^{\mathrm{b}}}\end{array}$ & $6.9 \pm 0.34 b[17](15 \%)$ & $8.0 \pm 0.89 a[15](10 \%)$ & $8.1 \pm 0.76 a[13](10 \%)$ & $11.4 \pm 1.19 a[5](40 \%)$ & $27.0 \pm 1.20 b[3]$ & $33.0 \pm 4.95 a[2]$ \\
\hline $\begin{array}{l}\text { Peanut raw } \\
{[20](80 \%)^{b}}\end{array}$ & $11.1 \pm 1.10 a[16](20 \%)$ & $11.9 \pm 2.09 a[8](40 \%)$ & $6.0 \pm 0.35 a[4](20 \%)$ & $11.0 \pm 1.27 a[4](0 \%)$ & $32.0^{\mathrm{C}}[1]$ & $31.3 \pm 5.04 a[3]$ \\
\hline Privet (berry) & 0.0 & - & - & - & - & - \\
\hline [20] $(100 \%)^{b}$ & [o] (100\%) & - & - & - & - & - \\
\hline
\end{tabular}

Means in each column followed by the same letter are not significantly different among themselves $(P<0.05$; Tukey test for all variables, except for total developmental time of female, in which was applied Student's $t$ test to compare between green bean pod and soybean pod).

${ }^{a}$ Initial number of nymphs; in parentheses percent mortality of each instar.

${ }^{\mathrm{b}}$ From second stadium to adult; in parentheses total mortality (percent) on each food.

${ }^{\mathrm{c}}$ Data was not considered for statistical analyses because only one individual survived. 


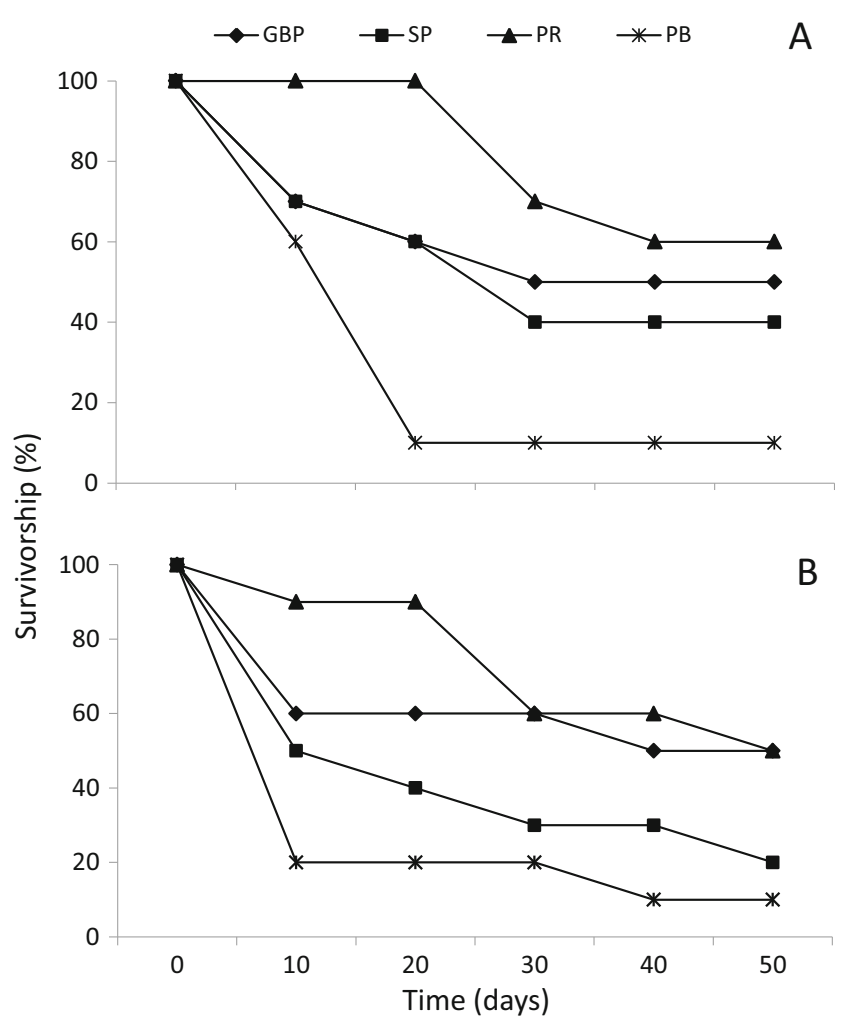

Fig 1 Survivorship (percent) up to 50 days of female (A) and male (B) adults of Euschistus cornutus feeding on different food sources in the laboratory. GBP green bean pod, $S P$ soybean pod, $P R$ peanut raw, and $P B$ privet berry.

feeding on peanut raw laying three times more egg masses/ female compared to those that fed on green bean pod, and five times more egg masses/female compared to those that fed on soybean pod. Regarding the total number of eggs per female, on peanut raw, a significantly greater number of eggs was produced by females, compared to the number of eggs laid on soybean pod, which did not differ from that on green bean pod. Egg hatchability reached the highest value on green bean pod (> than $75 \%$ ), significantly greater than on peanut raw, wherein only ca. $40 \%$ of the eggs hatched; on soybean pod, an intermediate value was observed (Table 2).
In relation to fresh body weight change, we observed the occurrence of a significant weight gain mostly during the first week of adult life on green bean pod $(26.9 \%)$, soybean pod (15.4\%), and peanut raw (32.5\%); whereas on privet berry, adults lost weight $(-14.8 \%)$. During the second and third weeks, in general, adults showed either weight gain or no weight gain, depending on the type of food provided. During the second week on green bean pod, adults showed a tiny loss of weight $(-0.1 \%)$, as well as on privet berry $(-2.9 \%)$; however, on peanut raw, adults showed a slight weight gain $(1.5 \%)$ and, on soybean pod, a high weight gain (17\%), which was significantly higher among all foods (Fig 2).

During the third week, no weight gain was observed on soybean pod, whereas on green bean pod and peanut raw, small weight gains occurred (7.7 and 3.2\%, respectively); on privet, adults lost weight $(-1.9 \%)$. In the last and fourth week, adults on all food sources tested showed lost weight, ranging from -1.5 to $-3.9 \%$, with no significant differences among them. Considering the total time evaluated ( 4 weeks), in general, fresh body weight gain occurred on all foods, except on privet berry, on which adults lost weight over time (Fig 2).

\section{Discussion}

The nymph mortality observed for E. cornutus on soybean pods was higher than that observed for another species of Neotropical Euschistus (E. heros for example) feeding on the same food (16.5\%, Villas Bôas \& Panizzi 1980, 28.6\%, Pinto \& Panizzi 1994, 13.3\%, Medeiros \& Megier 2009, 47.5\%, Azambuja et al 2013) or feeding on the fruits of the weed Euphorbia heterophylla L. (21.5\%, Pinto \& Panizzi 1994). Azambuja et al (2013) also observed that even providing a standard diet (composed by a mixture of green bean pod, privet fruit, and peanut raw) used to rear stink bugs in the laboratory, the total nymph mortality of $E$. heros was high (47.5\%). Mortality of all nymphs of E. cornutus on privet was also observed for the Nearctic E. servus (Say) feeding on another species of privet, Ligustrum sinense Lour.; however,
Table 2 Reproductive performance of females Euschistus cornutus feeding on different food sources in laboratory conditions.

\begin{tabular}{|c|c|c|c|c|c|}
\hline \multirow[t]{2}{*}{ Food source } & \multirow{2}{*}{$\begin{array}{l}\text { Females laying eggs } \\
\text { (\%) }\end{array}$} & \multirow{2}{*}{$\begin{array}{l}\text { Pre-oviposition time } \\
\text { (days) }\end{array}$} & \multicolumn{2}{|c|}{ Number/Female } & \multirow{2}{*}{$\begin{array}{l}\text { Egg hatch } \\
(\%)\end{array}$} \\
\hline & & & $\begin{array}{l}\text { Egg } \\
\text { masses }\end{array}$ & Eggs & \\
\hline $\begin{array}{l}\text { Green bean } \\
\text { pod }\end{array}$ & $60[6]^{a}$ & $75.3 \pm 23.4 a$ & $5.5 \pm 1.3 b$ & $74.3 \pm 22.1 \mathrm{ab}$ & $76.7 \pm 6.3 a$ \\
\hline Soybean pod & $40[4]$ & $44.5 \pm 7.6 a$ & $3.0 \pm 1.1 b$ & $22.3 \pm 8.6 b$ & $66.7 \pm 14.2 \mathrm{ab}$ \\
\hline Peanut raw & $60[6]$ & $40.0 \pm 7.6 a$ & $15.0 \pm 0.7 a$ & $162.8 \pm 39.6 a$ & $40.8 \pm 4.6 b$ \\
\hline Privet (berry) & o [o] & - & - & - & - \\
\hline
\end{tabular}

Means in each column followed by the same letter do not differ significantly $(P<0.05$; Tukey test).

${ }^{\text {a }}$ Number of adults that oviposited. 


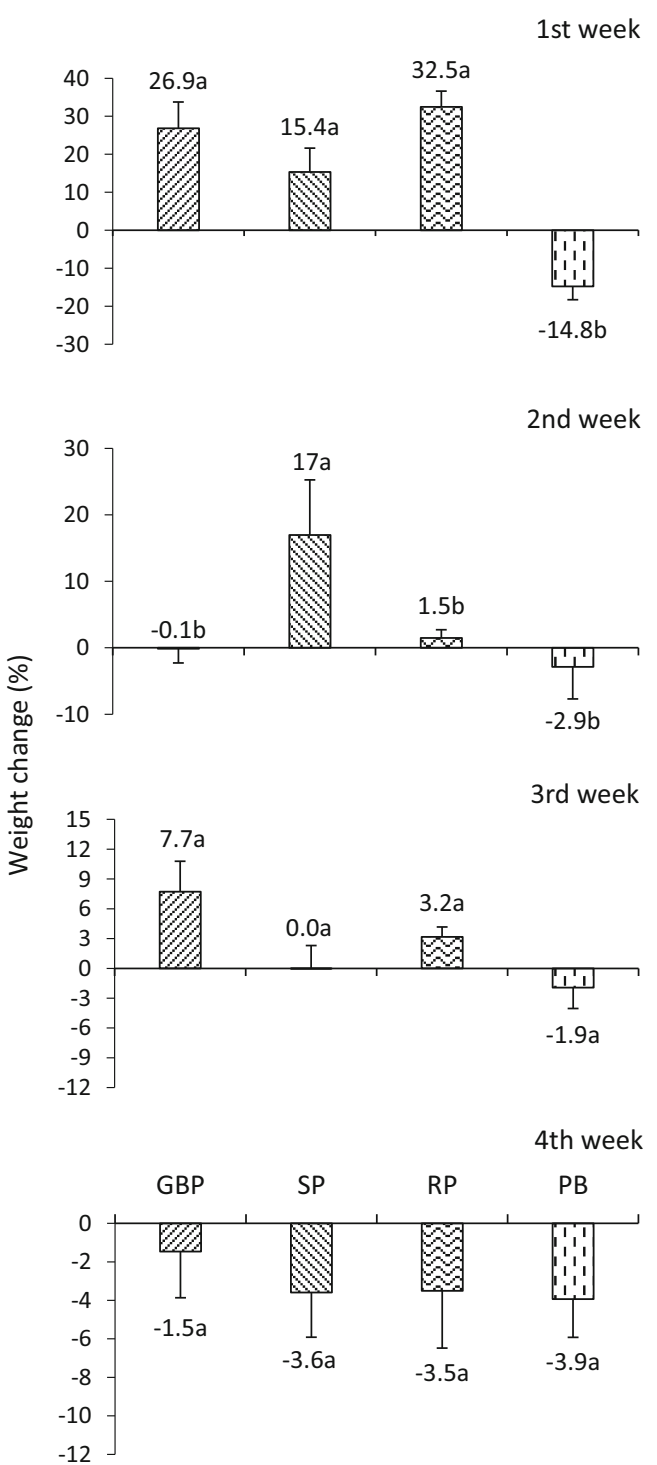

Fig 2 Fresh body weight gain (percent) of adult (female + male) Euschistus cornutus during the first 4 weeks of adult life feeding on different food sources in the laboratory. GBP green bean pod, $S P$ soybean pod, $P R$ peanut raw, and $P B$ privet berry. Means followed by the same letter among foods in each week do not differ significantly using the Tukey test $(P<0.05)$.

this last species on soybean showed a very low mortality (8.0\%) (Jones 1979).

The nymph developmental time (second to fifth instar) observed for E. cornutus on the foods tested on which they were able to complete development is higher than the time spent by $E$. heros to complete development on soybean and on E. heterophylla (range from 20.8 to 23.9 days) (Villas Bôas \& Panizzi 1980, Pinto \& Panizzi 1994). However, it was similar for $E$. heros to complete development on soybean structures (range from 30.0 to 36.6 days) (Azambuja et al 2013), and for E. servus on several plants including soybean (24.0 to 46.3 days) (Jones 1979).
Adult body weight of $E$. cornutus at emergence day of ca. $70 \mathrm{mg}$ (mean of female and male) on both soybean pod and on green bean pod is similar to the weight of $E$. heros reared on soybean pod (67 mg, Meneguin et al 1989, $75 \mathrm{mg}$, Medeiros \& Megier 2009), and on standard diet $(75.6 \mathrm{mg}$, Azambuja et al 2013). In addition, it was higher than that on green bean (61 mg) (Meneguin et al 1989) and on soybean pod (range from 62.5 to $65.7 \mathrm{mg}$ ) (Azambuja et al 2013).

Survivorship of about $50 \%$ of adults after 50 days (except males on soybean pod $=20 \%$ ) on all food sources tested, except on privet berry, suggest their suitability for E. cornutus adult life. Although total longevity was not calculated because observations were discontinued on day 50 , the relatively high survivorship up to this day suggests a mean total longevity of at least 50 days. This value of survivorship at day 50 is similar to that observed for $E$. heros feeding on the weed Acanthospermum hispidum DC. (Compositae) in the green house (Panizzi \& Rossi 1991), and lower than those observed for $E$. heros feeding on soybean $(80 \%$, Pinto \& Panizzi 1994, 70\%, Medeiros \& Megier 2009) or on E. heterophylla (70\%) (Pinto \& Panizzi 1994).

Adult reproduction with the greater fecundity of females fed on peanut raw and, to a lesser extent, on green bean pod is in agreement with data of several species of phytophagous stink bugs that show enhanced fecundity when feeding on these foods alone or combined (e.g., Sailer 1952, Harris \& Todd 1981, Jones \& Brewer 1987, Silva et al 2008, 2011, Medal et al 2012). Peanut plus green bean pod is recommended and used worldwide as a standard food to keep stink bugs colony in the laboratory (e.g., Jones 1985). Moreover, recently developed artificial diets to rear $E$. heros successfully are based on lyophilized peanut seed raw plus green bean pod (Mendonza et al 2016). On soybean pod and green bean pod, E. cornutus fecundity was, in general, similar which demonstrates that on these two crops, it may become a pest, particularly in the former. This suspicion is reinforced because the majority of the records available of E. cornutus on plants is on soybean (see discussion ahead).

The fact that $E$. cornutus adult increased in fresh body weight on green bean pod, soybean pod, and raw peanut during the first 3 weeks of adult life further support the previous data discussed and reinforce the suitability of these foods sources for adult biology. In a similar way, the fact that bugs did not gain and, actually, lost weight on privet berry confirms its inadequacy as a food source for this particular stink bug species. For other species of pentatomids, however, it has allowed not only body weight gain but also promoted increased fecundity (Panizzi et al 1996, Panizzi \& Mourão 1999, Coombs 2004).

Data obtained for E. cornutus deposited in insect collections in Brazil indicated that it occurs in the Southeast and South regions (Fig 3). The 46 records in where it was collected on different plants range from $19^{\circ}$ to $31^{\circ} \mathrm{S}$ latitude 


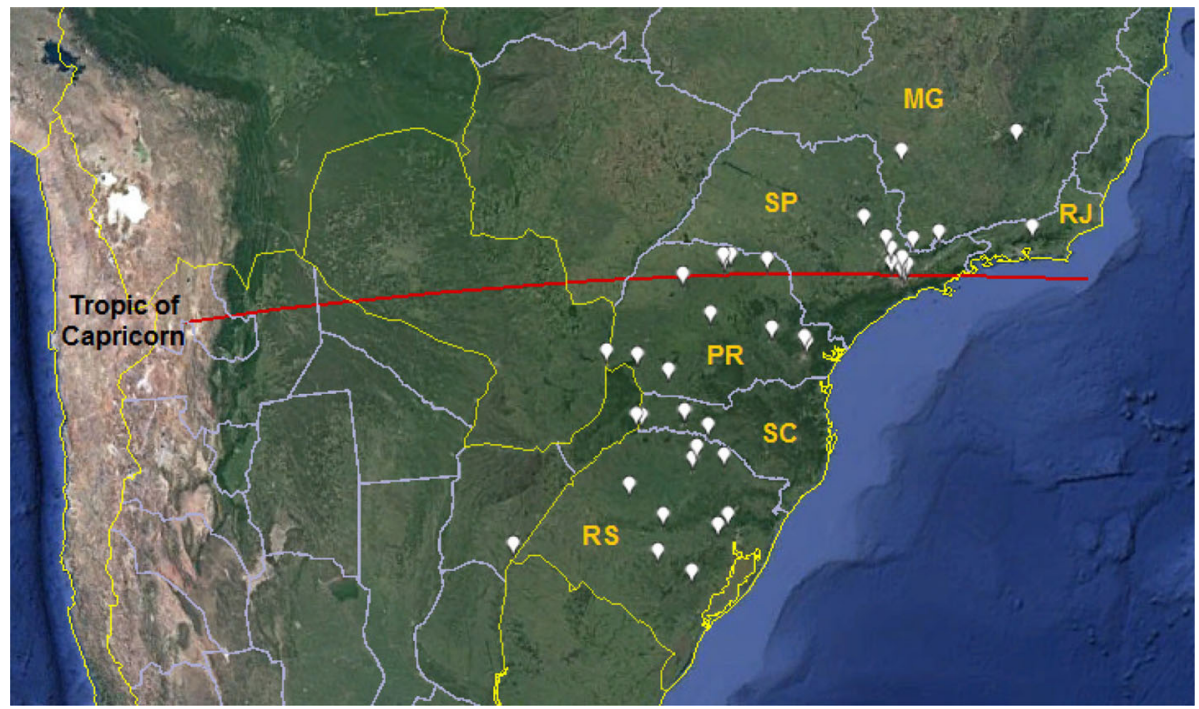

Fig 3 Records on the geographical distribution of adult Euschistus cornutus collected in Brazil [based on specimens deposited in insect collections at Embrapa Soybean, Embrapa Wheat, Federal University of Rio Grande do Sul (UFRGS), Federal University of Paraná (UFPR), and Zoobotanical Foundation of Rio Grande do Sul State (FZB)]. White arrows indicate the locations of collections. RS Rio Grande do Sul, SC Santa Catarina, PR Paraná (South region), SP São Paulo, MG Minas Gerais, RJ Rio de Janeiro (Southeast region).

Table 3 Locations, dates, and plants on where Euschistus cornutus were collected in South and Southeast Brazil [data based on records from insect collections at Embrapa Soybean, Embrapa Wheat, Federal University of Paraná (UFPR), Federal University of Rio Grande do Sul (UFRGS), and Zoobotanical Foundation of Rio Grande do Sul State (FZB)].

\begin{tabular}{|c|c|c|c|c|}
\hline Location & Date (month/day/year or month/year) & Host plant & Collector & Latitude \\
\hline Santa Teresa-ES & $11 / 30 / 1967$ & - & C Elias \& CT Elias & $19^{\circ} 56^{\prime} 09^{\prime \prime}$ \\
\hline Catas Altas-MG & $03 / 1963$ & - & F Werner, U Martins \& L Silva & $20^{\circ} 09^{\prime} 15^{\prime \prime}$ \\
\hline Passos-MG & $11 / 1961$ & - & C Elias & $20^{\circ} 44^{\prime} 16^{\prime \prime}$ \\
\hline Rio Claro-SP & 09/04/1993 & - & FM Bianchi & $22^{\circ} 24^{\prime} 15^{\prime \prime}$ \\
\hline Guapimirim-RJ & 03/01/1969 & - & Fragoso & $22^{\circ} 32^{\prime} 25^{\prime \prime}$ \\
\hline Campos do Jordão-SP & $24 / 01 / 1963$ & - & J Guimarães, L Silva \& A Rocha & $22^{\circ} 45^{\prime} 26^{\prime \prime}$ \\
\hline Campinas-SP & 06/04/1977 & Passion fruit ${ }^{a}$ & I Sazima \& B Amaral & $22^{\circ} 54^{\prime} 21^{\prime \prime}$ \\
\hline Joanópólis-SP & 03/1992 & - & F Sileira & $22^{\circ} 55^{\prime} 52^{\prime \prime}$ \\
\hline Jundiaí-SP & $27 / 10 / 1976$ & - & E Oliveira & $23^{\circ} 10^{\prime} 17^{\prime \prime}$ \\
\hline Rolândia-PR & $01 / 23 / 1980$ & Soybean ${ }^{b}$ & AR Panizzi & $23^{\circ} 18^{\prime} 35^{\prime \prime}$ \\
\hline Jundiaí do Sul-PR & $10 / 06 / 1986$ & - & - & $23^{\circ} 26^{\prime} 13^{\prime \prime}$ \\
\hline Londrina-PR & 03/01/1981 & Soybean ${ }^{b}$ & AR Panizzi & $23^{\circ} 18^{\prime} 37^{\prime \prime}$ \\
\hline Cantareira-SP & - & - & - & $23^{\circ} 24^{\prime} 23^{\prime \prime}$ \\
\hline Arapongas-PR & - & - & - & $23^{\circ} 25^{\prime} 08^{\prime \prime}$ \\
\hline Barueri-SP & $11 / 1965$ & - & K Lenko & $23^{\circ} 31^{\prime} 09^{\prime \prime}$ \\
\hline Guaianazes-SP & $02 / 1950$ & - & M Carrera & $23^{\circ} 34^{\prime} 48^{\prime \prime}$ \\
\hline São Paulo-SP & $16 / 05 / 1986$ & - & L Buckup & $23^{\circ} 39^{\prime} 02^{\prime \prime}$ \\
\hline Sto. André-SP & $02 / 1962$ & - & L Stowbunenko & $23^{\circ} 39^{\prime} 50^{\prime \prime}$ \\
\hline S. Bern. do Campo-SP & 11/1959 & - & W Bokermann & $23^{\circ} 45^{\prime} 29^{\prime \prime}$ \\
\hline Terra Boa-PR & $12 / 10 / 1975$ & - & - & $23^{\circ} 45^{\prime} 36^{\prime \prime}$ \\
\hline Pitanga-PR & - & - & - & $24^{\circ} 43^{\prime} 25^{\prime \prime}$ \\
\hline Ponta Grossa-PR & $11 / 1938$ & - & Camargo & $25^{\circ} 07^{\prime} 50^{\prime \prime}$ \\
\hline Al. Tamandaré-PR & 04/1983-09/1984 & Bracatinga (tree) ${ }^{c}$ & EC Costa & $25^{\circ} 21^{\prime} 30^{\prime \prime}$ \\
\hline Curitiba-PR & 03/18/1966 & - & Oliveira \& Graf & $25^{\circ} 28^{\prime} 54^{\prime \prime}$ \\
\hline
\end{tabular}


Table 3 (continued)

\begin{tabular}{|c|c|c|c|c|}
\hline Location & Date (month/day/year or month/year) & Host plant & Collector & Latitude \\
\hline Foz do Iguaçu-PR & $07 / 12 / 1966$ & - & - & $25^{\circ} 32^{\prime} 49^{\prime \prime}$ \\
\hline Capanema-PR & $03 / 27 / 2002$ & Soybean ${ }^{\mathrm{b}}$ & WA Perez & $25^{\circ} 40^{\prime} 19^{\prime \prime}$ \\
\hline Fco. Beltrão-PR & $12 / 30 / 2014$ & Soybean ${ }^{\mathrm{b}}$ & T Lucini & $26^{\circ} 04^{\prime} 52^{\prime \prime}$ \\
\hline Fco. Beltrão-PR & $12 / 30 / 2014$ & Solanum atropurpureum L. & T Lucini & $26^{\circ} 04^{\prime} 52^{\prime \prime}$ \\
\hline Fco. Beltrão-PR & $12 / 30 / 2014$ & Hybanthus bigibbosus (St. Hil.) Haffl. & T Lucini & $26^{\circ} 04^{\prime} 52^{\prime \prime}$ \\
\hline Chapecó-SC & 03/09/1981 & Soybean $^{\text {b }}$ & AR Panizzi & $27^{\circ} 05^{\prime} 47^{\prime \prime}$ \\
\hline Guatambú-SC & $12 / 2003-12 / 2004$ & Wild vegetation & FV Baldo & $27^{\circ} 05^{\prime} 50^{\prime \prime}$ \\
\hline Derrubadas-RS & $10 / 2003-05 / 2005$ & Wild vegetation & LS Schmidt \& A Barcellos & $27^{\circ} 08^{\prime} 44^{\prime \prime}$ \\
\hline Itapiranga-SC & 01/09/1953-01/1954 & - & - & $27^{\circ} 10^{\prime} 08^{\prime \prime}$ \\
\hline Marcelino Ramos-RS & $11 / 1940$ & - & - & $27^{\circ} 27^{\prime} 43^{\prime \prime}$ \\
\hline Sertão-RS & $29 / 11 / 2007$ & - & PRVS Pereira & $27^{\circ} 59^{\prime} 26^{\prime \prime}$ \\
\hline Lagoa Vermelha-RS & 29/10/1988 & - & JAM Fernandes & $28^{\circ} 12^{\prime} 48^{\prime \prime}$ \\
\hline Passo Fundo-RS & 03/10/1981 & Soybean $^{\text {b }}$ & AR Panizzi & $28^{\circ} 15^{\prime} 46^{\prime \prime}$ \\
\hline Passo Fundo-RS & $11 / 07 / 2008$ & Wheat $^{d}$ & PRVS Pereira & $28^{\circ} 15^{\prime} 46^{\prime \prime}$ \\
\hline Passo Fundo-RS & $03 / 23 / 2016$ & Black jack $^{\mathrm{e}}$ & AR Panizzi & $28^{\circ} 15^{\prime} 46^{\prime \prime}$ \\
\hline Jóia-RS & $12 / 2007-04 / 2009$ & Different crops & MAF Agüero & $28^{\circ} 50^{\prime} 47^{\prime \prime}$ \\
\hline Agudo-RS & 24/04/1975 & - & EV Jann & $29^{\circ} 38^{\prime} 07^{\prime \prime}$ \\
\hline Montenegro-RS & 08/10/2009 & - & YEA Gadelha & $29^{\circ} 41^{\prime} 17^{\prime \prime}$ \\
\hline Triunfo-RS & $05 / 02 / 2003$ & - & MG Araújo \& A Barcellos & $29^{\circ} 56^{\prime} 34^{\prime \prime}$ \\
\hline Barra do Quaraí-RS & $03 / 2003-01 / 2004$ & Wild vegetation & PRS Bunde & $30^{\circ} 10^{\prime} 25^{\prime \prime}$ \\
\hline Caçapava do Sul-RS & $04 / 2003-04 / 2005$ & Wild vegetation & PRS Bunde & $30^{\circ} 32^{\prime} 13^{\prime \prime}$ \\
\hline Canguçu-RS & $04 / 2003-04 / 2004$ & Wild vegetation & PRS Bunde & $31^{\circ} 05^{\prime} 07^{\prime \prime}$ \\
\hline
\end{tabular}

${ }^{\text {a }}$ Passiflora edulis Sims.

${ }^{\mathrm{b}}$ Glycine max (L.) Merrill.

${ }^{\mathrm{c}}$ Mimosa scrabella Benth.

${ }^{\mathrm{d}}$ Triticum sativum $\mathrm{L}$.

${ }^{\mathrm{e}}$ Bidens pilosa $\mathrm{L}$.

(Table 3). The most common cultivated host plant was soybean. Along with the observation of E. cornutus on the solanaceous $S$. atropurpureum in Francisco Beltrão as referred, several specimens of $E$. heros were also observed on this last plant. Apparently, stink bugs on the genus Euschistus like to feed on solanaceous plants; Medeiros \& Megier (2009) reported $E$. heros feeding on fruits of three species of solanaceous plants in Rio Grande do Sul state.

In conclusion, results of these laboratory studies with nymphs and adults of $E$. cornutus coupled with analysis of specimens deposited in insect collections plus field observations suggest that this stink bug has potential to become a pest of soybean and/or of green bean. Despite its high mortality, on these two food sources tested, plus peanut raw, nymphs and adults were able to develop, survive for long period, and to reproduce. The individuals that are able to complete development may form an adapted population to these foods and eventually become pests with time. Because soybean is largely cultivated in the neotropics, it is more likely that $E$. cornutus will move from the wild vegetation and become abundant on this crop. This happening, additional studies will be needed to evaluate its potential impact on grain yield mitigation on this crop.

Acknowledgements We thank Jocélia Grazia (UFRGS), Lúcia Massutti de Almeida (UFPR), and Aline Barcellos Prates dos Santos (FZB - RS) for information on records of the geographical distribution of $E$. cornutus. And two anonymous reviewers for critically reading the manuscript. This study was partially supported by a National Council of Research and Technology of Brazil (CNPq) grant number 471517/2012-7 to A. R. P., and by a scholarship from CAPES (Ministry of Education) of Brazil to T. L. We also thank the Embrapa Unit at Passo Fundo, RS, for support. Approved by the Publication Committee of the Embrapa Wheat, Passo Fundo, RS, Brazil under number 5397/2016.

\section{References}

Azambuja R, Degrande PE, Pereira FF (2013) Comparative biology of Euschistus heros (F.) (Hemiptera: Pentatomidae) feeding on cotton and soybean reproductive structures. Neotrop Entomol 42:359-365 
Barth MRA, Grazia J (2012) Morfologia comparada da genitália de fêmea de seis espécies de Euschistus Dallas (Hemiptera: Pentatomidae). https://www.lume.ufrgs.br/bitstream/handle/10183/64537 /Poster_23786.pdf?sequence=2 Acessed 15 July 2015

Coombs M (2004) Broadleaf, Ligustrum lucidum Aiton (Oleaceae), a late-season host for Nezara viridula (L.), Plautia affinis Dallas and Glaucias amyoti (Dallas) (Hemiptera: Pentatomidae) in northern New South Wales, Australia. Austr J Entomol 43:335-339

Fehr WR, Caviness CE, Burmood DT, Pennington JS (1971) Stage of development descriptions for soybeans, Glycine $\max ($ L.) Merrill. Crop Sci 11:929-930

Froeschner RC (1988) Family Pentatomidae Leach, 1815. the stink bugs. In: Henry TJ, Froeschner RC (eds) Catalog of the Heteroptera, or true bugs, of Canada and the continental United States. EJ Brill, Leiden, pp 544-597

Harris VE, Todd JW (1981) Rearing the southern green stink bug, Nezara viridula, with relevant aspects of its biology. J Ga Entomol Soc 16:203210

Jones WA Jr (1979) The distribution and ecology of pentatomid pests of soybeans in South Carolina. PhD thesis, Clemson University, Clemson, $\mathrm{SC}, \mathrm{p} 114$

Jones WA Jr (1985) Nezara viridula. In: Singh P, Moore RF (eds) Handbook of insect rearing. Elsevier Sci Publ BV, Amsterdam, pp 339-343

Jones WA Jr, Brewer FD (1987) Suitability of various host plant seeds and artificial diets for rearing Nezara viridula (L.). J Agric Entomol 4:223232

Kirkaldy GW (1909) Catalogue of the Hemiptera (Heteroptera), vol. I. Cimicidae. Felix L. Dames Ed., Berlin, p 392

Medal J, Smith T, Fox A, Santa Cruz A, Poplin A, Hoedges A (2012) Rearing the brown marmorated stink bug Halyomorpha halys (Heteroptera: Pentatomidae). Fla Entomol 95:800-802

Medeiros L, Megier GA (2009) Ocorrência e desempenho de Euschistus heros (F.) (Heteroptera: Pentatomidae) em plantas hospedeiras alternativas no Rio Grande do Sul. Neotrop Entomol 38:459-463

Mendonza AC, da Rocha ACP, Parra JRP (2016) Lyophilized artificial diet for rearing the Neotropical Euschistus heros (Hemiptera: Pentatomidae). J Insect Sci 16:1-9

Meneguin AM, Rossini MC, Panizzi AR (1989) Desempenho de ninfas e adultos de Euschistus heros (F.) (Hemiptera: Pentatomidae) em frutos verdes de amendoim-bravo Euphorbia heterophylla (Euphorbiaceae) e em sementes e vagens de soja. Res Congr Bras Entomol 12 1:43
Panizzi AR, Mourão AP (1999) Mating, ovipositional rhythm and fecundity of Nezara viridula (L.) (Heteroptera: Pentatomidae) fed on privet, Ligustrum lucidum Thunb., and on soybean, Glycine max (L.) Merrill fruits. An Soc Entomol Brasil 28:35-40

Panizzi AR, Rossi CE (1991) The role of Acanthospermum hispidum in the phenology of Euschistus heros and of Nezara viridula. Entomol Exp Appl 59:67-74

Panizzi AR, Corrêa BS, Gazzoni DL, Oliveira EB, Newman GG, Turnipseed SG (1977) Insetos da soja no Brasil. Embrapa-Cnpso, Londrina, Tec Bol $1: 20$

Panizzi AR, Vivan LM, Corrêa-Ferreira BS, Foerster LA (1996) Performance of southern green stink bug (Heteroptera: Pentatomidae) nymphs and adults on a novel food plant (Japanese privet) and other hosts. Ann Entomol Soc Am 89:822-827

Panizzi AR, Bueno AF, Silva FAC (2012) Insetos que atacam vagens e grãos. In: Hoffmann-Campo CB, Corrêa-Ferreira BS, Moscardi F (eds) Soja: manejo integrado de insetos e outros artrópodes-praga. Embrapa Editora, Brasília, pp 335-398

Pinto SB, Panizzi AR (1994) Performance of nymphal and adult Euschistus heros (F.) on milkweed and on soybean and effect of food switch on adult survivorship, reproduction and weight gain. An Soc Entomol Brasil 23:549-555

R Development Core Team (2014) R: A language and environment for statistical computing. $R$ foundation for statistical computing, Vienna, Austria

Rolston LH (1982) A revision of Euschistus Dallas subgenus Lycipta Stål (Hemiptera: Pentatomidae). Proc Entomol Soc Wash 84:281-296

Sailer RI (1952) A technique for rearing certain Hemiptera. USDA Dept Agric, Bur Ent, PI Quarantine, Gainesville, p 5

Saluso A, Xavier L, Silva FAC, Panizzi AR (2011) An invasive pentatomid pest in Argentina: Neotropical brown stink bug, Euschistus heros (F.) (Hemiptera: Pentatomidae). Neotrop Entomol 40:704-705

Silva CC, Laumann RA, Blassioli MC, Pareja M, Borges M (2008) Euschistus heros mass rearing technique for the multiplication of Telenomus podisi. Pesq Agropec Bras 43:575-580

Silva FAC, Calizotti GS, Panizzi AR (2011) Survivorship and egg production of phytophagous pentatomids in laboratory rearing. Neotrop Entomol 40:35-38

Villas Bôas GL, Panizzi AR (1980) Biologia de Euschistus heros (Fabricius, 1798) em soja [Glycine max (L.) Merrill]. An Soc Entomol Brasil 9: 105113 